\title{
INFLUENCE OF PACLOBUTRAZOL ON THE GROWTH AND PHOTOSYNTHESIS OF SEQUOIA SEMPERVIRENS SEEDLINGS
}

\author{
Shuming $\mathrm{JU}^{1,2^{*}}$, Delan $\mathrm{XU}^{1}$, Cuiying $\mathrm{ZHAN}^{1}$, Lingzhen $\mathrm{JI}^{1}$, \\ Tingchao YIN ${ }^{1}$, Zhenglei LI ${ }^{1}$, Zhongqin $\mathrm{LU}^{1}$ \\ ${ }^{1}$ School of Environment, Xuzhou Institute of Technology, Xuzhou Jiangsu 221111, China \\ ${ }^{2}$ Jiangsu Laboratory of Pollution Control and Resource Reuse, Xuzhou Jiangsu 221111, China
}

Received: October 2018; Accepted: June 2019

\begin{abstract}
Paclobutrazol (PAC), as a commonly used plant regulator, has the important function of improving the plant's stress resistance. Sequoia sempervirens Endl. is a large caliber, fast-growing timber species and one of the world's five major landscaping tree species. This study researched the effects of spraying PAC on the growth and photosynthetic activity of $S$. sempervirens seedlings. The results showed the plant height and the plant crown diameter were decreased significantly with the increase in PAC concentration (500 $\left.3,000 \mathrm{mg} \cdot \mathrm{dm}^{-3}\right)$. However, the ground shoot diameter, net photosynthetic rate, stomatal conductance, intercellular $\mathrm{CO}_{2}$ concentration, transpiration rate, actual photochemical quantum yield, and photosynthetic electron transport rate all showed the trend of increasing first reaching the maximum at $2,000 \mathrm{mg} \cdot \mathrm{dm}^{-3}$ and then decreased. Water use efficiency showed the opposite trend. Spraying 2 times was better than once. The conclusion suggests that PAC can protect the photosynthetic activity and improve the resistance of S. sempervirens seedlings under natural cooling and draught in autumn and winter.
\end{abstract}

Keywords: plant growth regulator; coast redwood; morphological indexes; chlorophyll fluorescence parameter; natural environmental stress

\section{INTRODUCTION}

Sequoia sempervirens Endl. is called coast redwood and belongs to relict plant, Cupressaceae (Zhang et al. 2015; Ma et al. 2005; Zuo et al. 2000). As large caliber fast-growing timber species and one of the world's five major landscaping tree species (Cown et al. 2013; Olson et al. 1990; Zuo et al. 2000, 2003; Ju et al. 2007), S. sempervirens has a very high value of cultivation and promotion. Now, S. sempervirens has been introduced and cultivated in more than 30 countries and successively introduced by the southern provinces in China after 1972 (Liu et al. 2006; Zuo et al. 2000, 2003). S. sempervirens was introduced to the Huaibei region in the central and east China in 2003 (Zuo et al. 2000; $\mathrm{Ju}$ et al. 2009). But because of low temperature and drought, some new shoot tips of S. sempervirens were damaged in winter (Ju et al. 2009; Zuo et al. 2000; Ma et al. 2005; Zhang et al. 2015), which restricted the cultivation of $S$. sempervirens in the central and eastern China. So, improving cold and drought resistance of S. sempervirens has become a problem that needs to be solved urgently for further application and dissemination.

Paclobutrazol (PAC) [(2RS,3RS)-1-(4-chlorophenyl)-4,4-dimethyl-2-(1,2,4-triazoly)-pentan-3-01], as a plant growth inhibitor, is used extensively in agriculture (Moreira et al. 2016; Hu et al. 2017; Teto et al. 2016; Mohammed et al. 2017; Davis et al. 1991). For example, Elanchezhian et al. (2015) introduced the effect of PAC on rice. PAC application enhanced the photosynthesis and transpiration rate in all the cultivars and alleviated the stress effects. 
Moreover, it can also decrease the decline in panicle weight and grain weight. PAC application can reduce the size of plants and increase the ability to resist both abiotic and biotic stresses, such as drought, salinity, flooding, cold, heat, and herbicides stress (Mohammadi et al. 2017; Rademacher 1995; Fletcher et al. 2000; Gilley \& Fletcher 1997; Baninasab 2009; Hunter \& Proctor 1994). Some studies showed that PAC could protect plants exposing to environmental stress by improving tissue compactness and physiological and biochemical activities (Baninasab 2009; Navarro et al. 2007).

The low temperature and arid in autumn and winter are the main stress factors to $S$. sempervirens in Xuzhou region of China, low temperature cause the stress to the S. sempervirens, and drought and wind can cause the rapid evaporation of water in shoots of S. sempervirens. The combined effects of these factors on S. sempervirens induce shoot tip to die. The research showed that PAC-induced alleviation of water-deficit damage in relation to photosynthetic characteristics (Dwivedi et al. 2017). On the basis of this, we can consider using the plant growth inhibitor to spray, limiting the second growth peak of S. sempervirens in the fall, so that the shoots of $S$. sempervirens can increase their degree of lignification and improve their resistance to low temperature and drought, so that they can survive winter safely in Xuzhou.

The purpose of the present study was to test the possibility that PAC application would protect S. sempervirens seedlings from damaging effects of natural cooling and draught in autumn and winter. Our specific objectives were (1) to determine the optimum PAC concentration and (2) and spraying frequency that would provide the best protection.

\section{MATERIALS AND METHODS}

\section{Site description}

The experimental field was located at a nursery base, Xuzhou Institute of Technology, in the east suburb of Xuzhou, Jiangsu province $\left(34^{\circ} 15^{\prime} \mathrm{N}\right.$, $117^{\circ} 11^{\prime} \mathrm{W}$ ), where it belongs to the warm temperate semi-humid monsoon climate, with strong spring winds, a warm humid summer, and a dry cold winter. The sunshine duration is 2,284 to $2,495 \mathrm{~h}$, while the sunshine rate is $52-57 \%$, the annual temperature is $14.58^{\circ} \mathrm{C}$, the average lowest temperature is $-10.52{ }^{\circ} \mathrm{C}$, the annual accumulated temperature is $5,143.5^{\circ} \mathrm{C}$, the average annual frost-free period is about 210 days, and the average annual rainfall is $853.1 \mathrm{~mm}$. The highest average temperature in November is $14^{\circ} \mathrm{C}$, and the lowest average temperature is $4{ }^{\circ} \mathrm{C}$ (the averages of the above agricultural meteorological indicators from 2010 to 2018; Table 1). The maximum temperature for the test day was $12{ }^{\circ} \mathrm{C}$ and the minimum temperature is $3{ }^{\circ} \mathrm{C}$.

\section{Plant culture and PAC treatments}

The experiment was carried out during September to November 2015. Uniform 2-year-old seedlings of S. sempervirens were taken as experimental materials. Five different concentrations of PAC solutions were prepared: $0 ; 500 ; 1,000 ; 2,000 ;$ and $3,000 \mathrm{mg} \cdot \mathrm{dm}^{-3}$. The PAC solutions were prepared by dissolving the appropriate dose of PAC (15\% wettable powder) into tap water. The spraying frequency of PAC with the same concentration was once (September 01, 2015) and twice (September 01 and 08, 2015). Spraying tap water served as a control. Seedlings were sprayed with PAC solutions until drops began to fall from the foliage. Seventy days after the treatment, growth indexes, photosynthetic parameters, and chlorophyll fluorescence parameters were measured.

\section{Measurements of growth index}

Growth indexes, including plant height, plant crown diameter, and ground shoot diameter, were measured before spraying PAC (September 01, 2015) and after treating with PAC for 70 days (November $20,2015)$ using the following formula:

plant height: $\mathrm{PH}(\mathrm{cm})=\mathrm{H}_{1}-\mathrm{H}_{2}$;

plant crown diameter: $\mathrm{PCD}(\mathrm{cm})=\mathrm{CD}_{1}-\mathrm{CD}_{2}$;

ground shoot diameter: $\mathrm{GSD}(\mathrm{mm})=\mathrm{SD}_{1}-\mathrm{SD}_{2}$; $\mathrm{H}_{1}, \mathrm{CD}_{1}$, and $\mathrm{SD}_{1}$ represented the plant height, plant crown diameter, and ground shoot diameter determined on September 01, 2015, respectively. $\mathrm{H}_{2}, \mathrm{CD}_{2}$, and $\mathrm{SD}_{2}$ represented the plant height, plant 
crown diameter, and ground shoot diameter determined on November 20, 2015, respectively. $\mathrm{CD}_{1}$ and $\mathrm{CD}_{2}$ represented the mean values of northsouth diameters and east-west diameters at different measuring times, respectively.

\section{Measurements of photosynthetic parameters}

The photosynthetic parameters, such as the net photosynthetic rate $\left(\mathrm{P}_{\mathrm{n}}\right)$, stomatal conductance $\left(\mathrm{G}_{\mathrm{s}}\right)$, transpiration rate $\left(\mathrm{T}_{\mathrm{r}}\right)$, and intercellular $\mathrm{CO}_{2}$ concentration $\left(\mathrm{C}_{\mathrm{i}}\right)$, were measured at 9:00-12:00 pm using a portable photosynthetic system (LI-6400, LI-Cor 6400 , USA). Measurements were performed on the third fully expanded leaves at $25 \pm 1{ }^{\circ} \mathrm{C}, 380 \pm$ $15 \mu \mathrm{mol} / \mathrm{mol}$ atmospheric $\mathrm{CO}_{2}$ concentration, and $600 \mu \mathrm{mol} \cdot \mathrm{m}^{-2} \cdot \mathrm{s}^{-1}$ saturating light at photosynthetically active photon flux density (PPFD) (Zhao et al. 2015, Januskaitiene 2011). Water use efficiency was measured using the formula WUE $=\mathrm{P}_{\mathrm{n}} / \mathrm{T}_{\mathrm{r}}$ (Cai et al. 2014). Five $S$. sempervirens seedlings were randomly selected for each treatment to determine the photosynthetic parameters.

\section{Measurements of chlorophyll fluorescence pa- rameters}

The third fully expanded leaf was selected to test the chlorophyll fluorescence parameters, the actual photochemical quantum yield (Yield) (Genty et al. 1989), photosynthetic electron transport rate (ETR) (Genty et al. 1989; Schreiber 2004) using chlorophyll spectrometer (MINI-PAM, Walz, Germany). Five $S$. sempervirens seedlings were randomly selected for each treatment to determine the chlorophyll fluorescence parameters at light condition (Photosynthetic active radiation in leaf chambers (PARi) $\left.1,000 \mu \mathrm{mol} \cdot \mathrm{m}^{-2} \cdot \mathrm{s}^{-1}\right)$, and temperature of $10^{\circ} \mathrm{C}$.

\section{Statistical analysis}

All means \pm standard deviation (SD) were calculated using SPSS 19 software, and one-way ANOVA was used to analyze the influence of different treatments on various indexes. Two-way ANOVA was used to analyze the interaction effects of PAC concentration and spraying times on growth indexes, photosynthetic parameters, and chlorophyll fluorescence parameters. Correlation between the measurement indicators was analyzed using Origin 8.0 software.

\section{RESULTS}

Effects of PAC on the growth of S. sempervirens seedlings

Compared to control, the treatment with PAC significantly inhibited the plant height and plant crown diameter of the S. sempervirens seedlings but significantly enhanced the ground shoot diameter, regardless whether the seedlings were sprayed once or twice (Table 2). The maximum shoot diameter was recorded at a concentration of $1,000 \mathrm{mg} \cdot \mathrm{dm}^{-3}$. Under natural cooling and drought in the autumn and winter, by spraying PAC twice at a concentration of $1,000 \mathrm{mg} \cdot \mathrm{dm}^{-3}$, the ground shoot diameter of $S$. sempervirens seedlings increased by $141.9 \%$ compared with the control. The results of a two-way ANOVA revealed an evident interaction between PAC concentration and spraying times that affected the plant height, plant crown diameter, and ground shoot diameter (Table 2).

Effects of PAC on the photosynthetic parameters of $S$. sempervirens seedlings

Table 3 showed the effects of PAC on $\mathrm{P}_{\mathrm{n}}, \mathrm{G}_{\mathrm{s}}, \mathrm{C}_{\mathrm{i}}$, and $\mathrm{T}_{\mathrm{r}}$ of the leaves of $S$. sempervirens seedlings. It could be observed that spraying PAC could make the S. sempervirens seedlings keep higher $\mathrm{P}_{\mathrm{n}}, \mathrm{G}_{\mathrm{s}}, \mathrm{C}_{\mathrm{i}}$, and $\mathrm{T}_{\mathrm{r}}$ than those of the control, which showed the trend of increased first and then decreased with the increase in PAC concentration, and then reached the maximum at a concentration of $2,000 \mathrm{mg} \cdot \mathrm{dm}^{-3}$ of PAC. Under the same concentration conditions, spraying twice had more powerful effect than spraying once, reaching a significant level (Table 3). Under natural cooling and drought in the autumn and winter, spraying twice PAC at a concentration of $2,000 \mathrm{mg} \cdot \mathrm{dm}^{-3}$, the $P_{n}, G_{s}, C_{i}$, and $T_{r}$ of $S$. sempervirens seedlings increased by $53.92 \%, 150.58 \%, 87.74 \%$, and $101.55 \%$ compared with the control, respectively. The two-way ANOVA results showed an obvious interaction between PAC concentration and spraying times that affected the $P_{n}, G_{s}, C_{i}$, and $T_{r}$ of $S$. sempervirens under the natural cooling and drought. Table 4 showed the correlation coefficients between $\mathrm{P}_{\mathrm{n}}$ and $\mathrm{G}_{\mathrm{s}}, \mathrm{C}_{\mathrm{i}}$, or $\mathrm{T}_{\mathrm{r}}$ of $S$. sempervirens seedlings treated with $\mathrm{PAC}$ and spraying times. The results indicated that the $\mathrm{G}_{\mathrm{s}}, \mathrm{C}_{\mathrm{i}}$, and $T_{r}$ were positively correlated with $P_{n}(p<0.01)$. 
Table 1. Agricultural meteorological indicators in Xuzhou area, China (2010-2018 years)

\begin{tabular}{|c|c|c|c|c|c|c|c|c|c|c|c|c|}
\hline \multirow{2}{*}{ Agrometeorological index } & \multicolumn{12}{|c|}{ Month } \\
\hline & 1 & 2 & 3 & 4 & 5 & 6 & 7 & 8 & 9 & 10 & 11 & 12 \\
\hline Average maximum temperature of the month $\left({ }^{\circ} \mathrm{C}\right)$ & 5 & 8 & 13 & 21 & 26 & 30 & 31 & 31 & 27 & 22 & 14 & 12 \\
\hline Average minimum temperature of the month $\left({ }^{\circ} \mathrm{C}\right)$ & -3 & -1 & 3 & 10 & 15 & 20 & 24 & 23 & 17 & 11 & 4 & -2 \\
\hline Average rainfall of the month (mm) & 18 & 20 & 36 & 47 & 66 & 107 & 241 & 133 & 72 & 52 & 27 & 14 \\
\hline
\end{tabular}

The data were taken from the weather network http://www.tianqi.com/qiwen/city_xuzhou/

Table 2. Effects of paclobutrazol (PAC) on the growth of S. sempervirens seedlings under natural cooling and drought

\begin{tabular}{|c|c|c|c|c|}
\hline $\begin{array}{c}\text { Spraying } \\
\text { times }\end{array}$ & $\mathrm{PAC}\left(\mathrm{mg} \cdot \mathrm{dm}^{-3}\right)$ & Plant height $(\mathrm{cm})$ & Plant crown diameter $(\mathrm{cm})$ & Ground shoot diameter $(\mathrm{mm})$ \\
\hline \multirow{5}{*}{1} & 0 & $47.7 \pm 2.1(100.0) \mathrm{a}$ & $85.2 \pm 10.7(100.0) \mathrm{a}$ & $6.7 \pm 0.8(100.0) \mathrm{e}$ \\
\hline & 500 & $36.8 \pm 2.2(77.2) b$ & $59.1 \pm 6.6(69.4) b$ & $9.8 \pm 0.7(146.3) \mathrm{d}$ \\
\hline & 1000 & $28.5 \pm 3.3(60.0) \mathrm{c}$ & $51.4 \pm 7.02(60.3) b$ & $14.6 \pm 0.6(218.9) \mathrm{a}$ \\
\hline & 2000 & $24.9 \pm 3.0(52.2) \mathrm{d}$ & $31.5 \pm 4.46(37.0) \mathrm{cd}$ & $12.9 \pm 0.9(192.5) b$ \\
\hline & 3000 & $18.4 \pm 1.5(38.6) \mathrm{e}$ & $22.6 \pm 3.38(26.5) \mathrm{de}$ & $10.5 \pm 0.9(156.7) \mathrm{cd}$ \\
\hline \multirow{5}{*}{2} & 0 & $47.9 \pm 2.7(100.0) \mathrm{a}$ & $88.5 \pm 7.78(100.0) \mathrm{a}$ & $6.2 \pm 0.5(100.0) \mathrm{e}$ \\
\hline & 500 & $29.2 \pm 2.9(61.0) \mathrm{c}$ & $52.2 \pm 7.66(59.0) b$ & $11.7 \pm 1.5(188.7) b c$ \\
\hline & 1000 & $21.6 \pm 3.1(45.1) \mathrm{de}$ & $38.2 \pm 3.83(43.2) \mathrm{c}$ & $15.0 \pm 1.5(241.9) \mathrm{a}$ \\
\hline & 2000 & $9.7 \pm 0.8(20.3) \mathrm{f}$ & $20.1 \pm 2.08(22.7) \mathrm{e}$ & $11.9 \pm 0.9(191.9) \mathrm{bc}$ \\
\hline & 3000 & $7.7 \pm 0.5(16.1) \mathrm{f}$ & $17.2 \pm 2.84(19.4) \mathrm{e}$ & $9.5 \pm 0.6(153.2) \mathrm{d}$ \\
\hline $\mathrm{F}$ & & 65.65 & 65.79 & 32.53 \\
\hline $\mathrm{p}$ & & $0.00^{* * *}$ & $0.00^{* *}$ & $0.00^{* * *}$ \\
\hline
\end{tabular}

Means followed by the same letter do not differ significantly at $\mathrm{p}=0.05$ according to the LSD test

Values are means \pm standard deviation errors, $n=5$

F statistic calculated for the interaction of the tested factors under the table

$p$ - probability of $\mathrm{F}$ statistic: $* *$ significant at $\mathrm{p}<0.01$ level

Table 3. Effects of paclobutrazol (PAC) on the $\mathrm{P}_{n}, \mathrm{G}_{\mathrm{s}}, \mathrm{C}_{\mathrm{i}}$, and $\mathrm{T}_{\mathrm{r}}$ in S. sempervirens seedlings under natural cooling and drought

\begin{tabular}{|c|c|c|c|c|c|}
\hline $\begin{array}{c}\text { Spraying } \\
\text { times }\end{array}$ & $\begin{array}{c}\mathrm{PAC} \\
\left(\mathrm{mg} \cdot \mathrm{dm}^{-3}\right)\end{array}$ & $\mathrm{P}_{\mathrm{n}}\left(\mu \mathrm{mol} \mathrm{CO} 2 \cdot \mathrm{m}^{-2} \cdot \mathrm{s}^{-1}\right)$ & $\mathrm{G}_{\mathrm{s}}\left(\mathrm{mmol} \mathrm{H}{ }_{2} \mathrm{O} \cdot \mathrm{m}^{-2} \cdot \mathrm{s}^{-1}\right)$ & $\mathrm{C}_{\mathrm{i}}\left(\mu \mathrm{mol} \mathrm{CO} 2 \cdot \mathrm{mol}^{-1}\right)$ & $\mathrm{T}_{\mathrm{r}}\left(\mathrm{mmol} \mathrm{H} \mathrm{H}_{2} \mathrm{O} \cdot \mathrm{m}^{-2} \cdot \mathrm{s}^{-1}\right)$ \\
\hline \multirow{5}{*}{1} & 0 & $4.90 \pm 0.26(100.00) \mathrm{e}$ & $12.018 \pm 0.47(100.00) \mathrm{h}$ & $157.52 \pm 10.16(100.00) \mathrm{h}$ & $0.32 \pm 0.02(100.00) \mathrm{h}$ \\
\hline & 500 & $5.52 \pm 0.31(112.70) \mathrm{d}$ & $14.28 \pm 0.38(118.82) \mathrm{g}$ & $177.26 \pm 6.69(112.53) \mathrm{g}$ & $0.37 \pm 0.01(115.89) \mathrm{g}$ \\
\hline & 1000 & $6.38 \pm 0.11(130.37) \mathrm{c}$ & $21.76 \pm 1.35(181.06) \mathrm{d}$ & $238.82 \pm 9.208(151.62) \mathrm{e}$ & $0.54 \pm 0.02(169.16) \mathrm{c}$ \\
\hline & 2000 & $6.66 \pm 0.21(135.95) b c$ & $24.78 \pm 1.44(206.19) b$ & $263.60 \pm 3.59(167.35) b$ & $0.58 \pm 0.01(180.69) \mathrm{b}$ \\
\hline & 3000 & $6.96 \pm 0.49(142.20) \mathrm{b}$ & $23.80 \pm 1.21(198.04) b c$ & $250.18 \pm 4.39(158.83) \mathrm{c}$ & $0.51 \pm 0.01(159.81) \mathrm{d}$ \\
\hline \multirow{5}{*}{2} & 0 & $4.94 \pm 0.34(100.00) \mathrm{e}$ & $12.06 \pm 0.47(100.00) \mathrm{h}$ & $158.62 \pm 1.34(100.00) \mathrm{h}$ & $0.32 \pm 0.03(100.00) \mathrm{h}$ \\
\hline & 500 & $6.13 \pm 0.39(123.95) \mathrm{c}$ & $17.00 \pm 1.30(140.87) \mathrm{f}$ & $200.76 \pm 14.13(126.57) \mathrm{f}$ & $0.41 \pm 0.02(126.63) \mathrm{f}$ \\
\hline & 1000 & $6.85 \pm 0.35(138.45) b$ & $23.08 \pm 1.01(191.31) \mathrm{c}$ & $260.10 \pm 11.45(163.98) b c$ & $0.57 \pm 0.02(176.47) b$ \\
\hline & 2000 & $7.61 \pm 0.50(153.92) \mathrm{a}$ & $30.23 \pm 0.57(250.58) \mathrm{a}$ & $297.79 \pm 12.86(187.74) \mathrm{a}$ & $0.65 \pm 0.01(201.55) \mathrm{a}$ \\
\hline & 3000 & $6.66 \pm 0.13(134.67) b c$ & $20.06 \pm 1.01(166.28) \mathrm{e}$ & $224.35 \pm 12.61(141.44) \mathrm{d}$ & $0.46 \pm 0.01(140.87) \mathrm{e}$ \\
\hline $\mathrm{F}$ & & 61.09 & 146.96 & $137.89 \pm$ & 257.11 \\
\hline $\mathrm{p}$ & & $0.00^{* *}$ & $0.00^{* *}$ & $0.00^{* *}$ & $0.00^{* *}$ \\
\hline
\end{tabular}

Note: see Table 2 
Table 4. Relationship of the $\mathrm{G}_{\mathrm{s}}, \mathrm{C}_{\mathrm{i}}, \mathrm{T}_{\mathrm{r}}$, WUE, Yield, and ETR with $\mathrm{P}_{\mathrm{n}}$ of $S$. sempervirens seedlings treated with PCA under natural cooling and drought

\begin{tabular}{cc}
\hline Linear regression equation & Correlation coefficient $(R)$ \\
\hline $\mathrm{Y}=0.144 \mathrm{X}_{1}+3.400$ & $0.924^{* *}$ \\
$\mathrm{Y}=0.018 \mathrm{X}_{2}+2.249$ & $0.926^{* *}$ \\
$\mathrm{Y}=7.186 \mathrm{X}_{3}+2.856$ & $0.844^{* *}$ \\
$\mathrm{Y}=-0.400 \mathrm{X}+11.706$ & $-0.523^{*}$ \\
$\mathrm{Y}=14.238 \mathrm{X}-1.481$ & $0.447^{*}$ \\
$\mathrm{Y}=0.368 \mathrm{X}+2.046$ & $0.547^{* *}$ \\
\hline
\end{tabular}

$Y$ represents the $P_{n}$

$\mathrm{X}_{1}, \mathrm{X}_{2}, \mathrm{X}_{3}, \mathrm{X}_{4}, \mathrm{X}_{5}$, and $\mathrm{X}_{6}$ represent the $\mathrm{G}_{\mathrm{s}}, \mathrm{C}_{\mathrm{i}}, \mathrm{T}_{\mathrm{r}}$, WUE, Yield, and ETR, respectively

${ }^{*}$ significant at the 0.05 level; ${ }^{* *}$ significant at the 0.01 level

Effects of PAC on WUE of S. sempervirens seedlings

Treatment with PAC significantly decreased WUE with the minimum observed at the concentrations of 1,000 and $2,000 \mathrm{mg} \cdot \mathrm{dm}^{-3}$ regardless of the number of spays (Fig. 1). When spraying with PAC was applied twice at the concentration of $2,000 \mathrm{mg} \cdot \mathrm{dm}^{-3}$, the WUE of S. sempervirens seedlings decreased by $24.29 \%$ compared to the control. Table 4 showed the correlation coefficients between $\mathrm{P}_{\mathrm{n}}$ and WUE of the leaves of $S$. sempervirens seedlings treated with PAC. The results indicated that the $\mathrm{P}_{\mathrm{n}}$ was negatively correlated with the WUE $(p<0.05)$.

Effects of PAC on the fluorescence parameters effect of $S$. sempervirens seedlings

Figure 2 showed that spaying PAC could maintained higher Yield and ETR, which showed the trend of increasing first and then decreasing with the increase in the PAC concentration, and reached the maximum at the concentration of $2,000 \mathrm{mg} \cdot \mathrm{dm}^{-3}$. Under the same concentration, the effect difference between spraying twice and spraying once was not obvious. Two-way ANOVA results indicated an interaction between the PAC concentrations and spraying times that affected the Yield and ETR in the leaves of $S$. sempervirens seedlings. Table 4 presented the correlation coefficients between $P_{n}$ and Yield and ETR in the leaves of $S$. sempervirens seedlings treated with different PAC concentrations and spraying times. The results indicated that the Yield and ETR were positively correlated with $P_{n}$. Two-way ANOVA analysis indicated that there was an obvious interaction between PAC concentration and spraying times action on Yield and ETR.

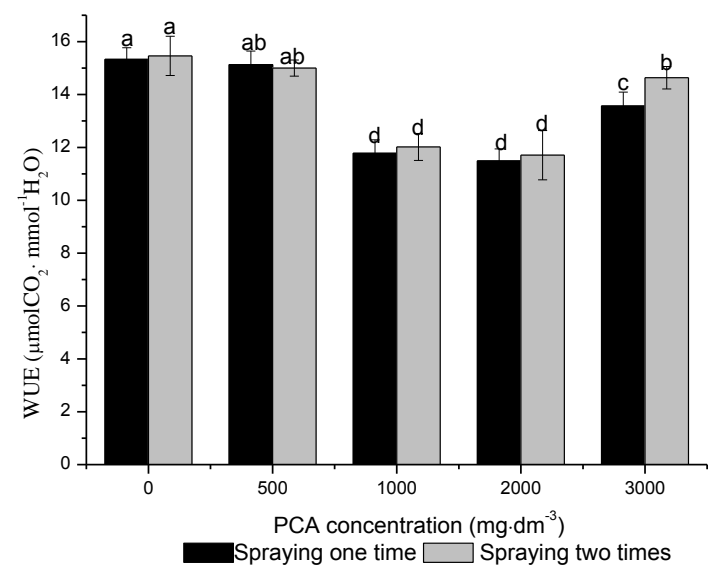

Fig. 1 Effects of PCA on the water use efficiency (WUE) in S. sempervirens seedlings under natural cooling. Significantly differences at $\mathrm{p}<0.05$ were showed with different letter. Interaction effects: $\mathrm{F}=116.897, \mathrm{p}<0.05$ 

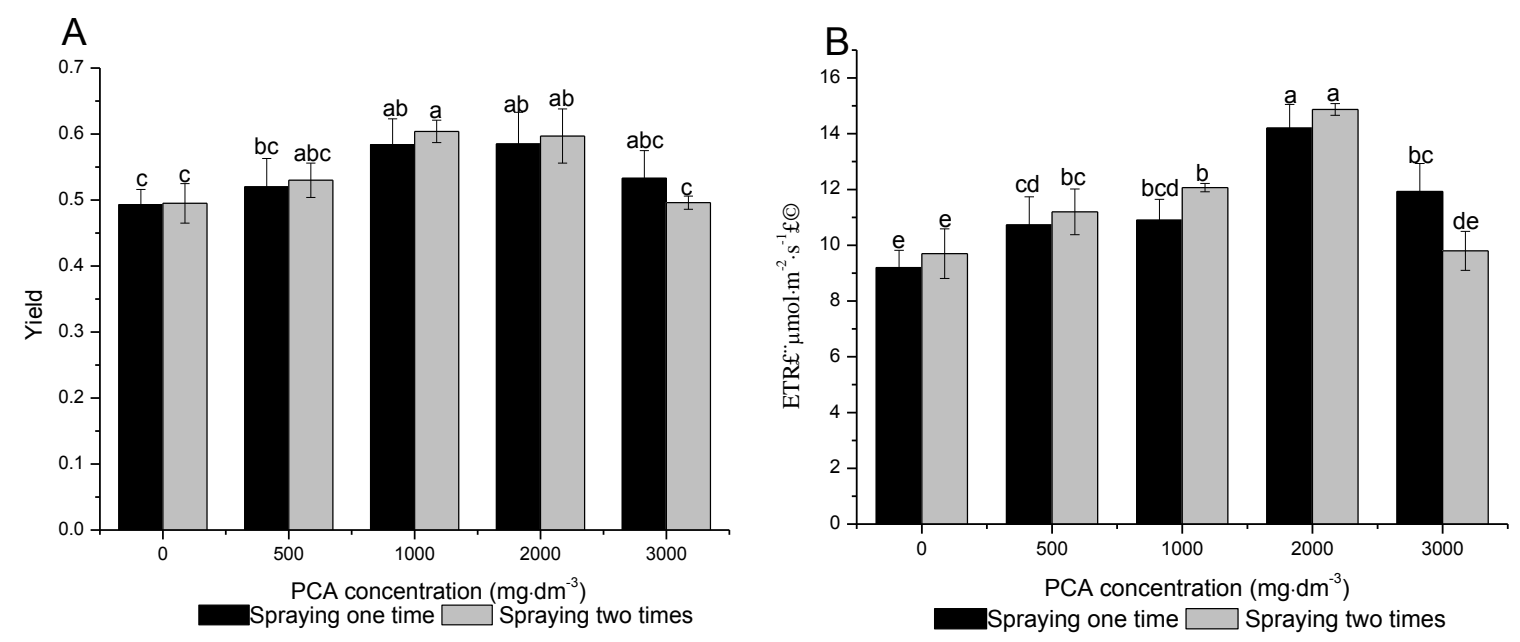

Fig. 2 Effects of PCA on the (A) photochemical quantum of PS II photochemistry (Yield) and (B) photosynthetic electron transport rate (ETR) in S. sempervirens seedlings under natural cooling. Significant differences at $p<0.05$ were showed with different letter. Interaction effects: $F=5.282, p<0.05$ for Yield; $F=20.419$, $p<0.05$ for ETR.

\section{DISCUSSION}

PAC is a plant growth inhibitor that can inhibit plant growth and regulate physiological activity in plants, especially under environmental stress. Some studies have showed that the effect of PAC on plants is closely related to the PAC concentration and spraying times (Teto et al. 2016; Pal et al. 2016; Navarro et al. 2007; Vu and Yelenosky 1992; Mohammed et al. 2017). Similarly, in our study, the spraying with PAC had a significant inhibitory effect on the plant height and plant crown diameter of S. sempervirens seedlings and increased shoot diameter and photosynthesis or fluorescence activity. When the concentration reaches $1,000-2,000 \mathrm{mg} \cdot \mathrm{dm}^{-3}$, the spraying effect of PAC was the best. Spraying twice had the most significant dwarf effect, and the shoot diameter was the largest.

Photosynthesis is the basis of plant survival and is the complex process to change the light energy into chemical energy (Bernacchi et al. 2013). At the same time, under the environmental stress, photosynthetic rate is also an important indicator to evaluate the plant resistance (Polishchuk et al. 2016; Sun et al. 2016; Hu et al. 2016a, b). Higher $\mathrm{P}_{\mathrm{n}}$ indicates the more organic matter is synthesized in plants, and the more energy for consumption, the stronger is the ability to resist environmental stress. Our results had shown that spraying PAC could maintain higher $\mathrm{P}_{\mathrm{n}}$ compared with the control. This indicated PAC application improved cold resistance of $S$. sempervirens. The result concur with the findings of Pal et al. (2016) who reported that PAC treatment increased $P_{n}$ and reduced drought injury in plant. Dwivedi et al. (2017) also considered that the application of PAC increased the drought resistance of wheat according to the improved photosynthetic characteristics.

Both stomatal and non-stomatal factors affect the photosynthetic rate; the values of $\mathrm{G}_{\mathrm{s}}$ and $\mathrm{C}_{\mathrm{i}}$ can be a useful criterion to determine whether photosynthesis is limited by stomatal closure or metabolic impairment (Jones 1985). When $\mathrm{G}_{\mathrm{s}}$ and $\mathrm{C}_{\mathrm{i}}$ decrease simultaneously, stomatal factors play a dominant role in regulating the photosynthetic rate, but when $\mathrm{G}_{\mathrm{s}}$ decreases and $\mathrm{C}_{\mathrm{i}}$ increases, non-stomatal factors play a dominant role (Velikova et al. 1999; Flexas \& Medrano 2002). In the present work, spraying PAC on $S$. sempervirens seedlings, the changes in $\mathrm{G}_{\mathrm{s}}$ and $\mathrm{C}_{\mathrm{i}}$ showed the trend of decreasing first and then increasing with the increase in PAC concentration and the changes in $\mathrm{G}_{\mathrm{s}}$ and $\mathrm{Ci}$ were the same. The stomatal factors played an important role and ultimately promoted photosynthesis. It indicated that the low temperature and drought could induce stomatal closure under the natural conditions of autumn and winter. Stomatal closure also limited the transpiration of the stomatal pathway, so, $\mathrm{T}_{\mathrm{r}}$ reduced, which led to 
a decrease in $P_{n}$. The spraying of PAC increased the resistance of $S$. sempervirens seedlings, improved the regulation of stomatal opening and closing, and increased the $\mathrm{P}_{\mathrm{n}}$. Stomatal opening increased the water evapotranspiration of the air pathways, increasing $T_{r}$ while reducing the WUE. Navarro et al. (2007) also suggested that spraying PAC stimulated a more efficient stomatal regulation, improved water status, and reduced water loss through limited transpiration, reducing the plant growth. Conover (1994) found that plants treated with PAC used less water than control. Mataa et al. (1998) reported that PAC application ameliorated photosynthetic reductions associated with water stress by maintaining higher photosynthetic and transpiration rate during water stress.

The higher photosynthetic efficiency of plants under environmental stress is probably due to the capacity of the absorption of light energy and the conversion of light energy being maintained to a certain extent. Yield and ETR, as the important fluorescence parameters, reflect the actual light energy conversion efficiency and actual photosynthetic ETR of a plant (Genty et al. 1989; Schreiber 2004). ETR and Yield are widely used in studies on environmental stress; Yield and ETR are suppressed under biological and abiotic stresses (Wang et al. 2012; Hu et al. 2016a, b; Yu et al. 2014). In the present study, Yield and ETR increased significantly in leaves of $S$. sempervirens seedlings treated with PAC. Correlation analysis showed that $P_{n}$ was positively correlated with Yield and ETR. This indicated that the spraying of PAC increased cold and drought resistance of $S$. sempervirens seedlings and improved $\mathrm{P}_{\mathrm{n}}$, partially ascribed to increasing ETR and Yield. Wang et al. (2012) came to similar conclusions; they reported that spraying PAC could increase the cold resistance of litchi in winter and increased the open proportion of PS II reaction center, promote photosynthetic electron transport, and improve the photosynthetic function of litchi leaves. The results of Yu et al. (2014) also revealed that the application of PAC could improve the cold resistance of Cymbidium seedlings by easing the hurt of the PS II reaction center, maintain both the primary capture capacity and assimilation efficiency of light energy, and, finally, ensure the photosynthesis capacity of Cymbidium seedlings. Baninasab (2009) and Moradi et al. (2017) reported that PAC ameliorated the injury caused by freezing stress and chlorophyll fluorescence ratio.

In conclusion, PAC spraying could limit the growth of $S$. sempervirens shoots, increased cold and drought resistance of plants, and improved the $\mathrm{P}_{\mathrm{n}}, \mathrm{G}_{\mathrm{s}}, \mathrm{C}_{\mathrm{i}}, \mathrm{T}_{\mathrm{r}}$, Yield, and ETR, while reducing the WUE on the $S$. sempervirens seedlings. The best protection was obtained for plants treated with PAC at a concentration of $1,000-2,000 \mathrm{mg} \mathrm{dm}^{-3}$. But the test time of the experimental data is in the middle of November when the daily temperature is $2-12{ }^{\circ} \mathrm{C}$, which is only chilling injury on the $S$. sempervirens shoots. However, the effect of low temperature below $0{ }^{\circ} \mathrm{C}$ on the $S$. sempervirens and the mitigative effect of PAC should be further studied.

\section{Acknowledgment}

This work was supported by the National Spark Plan Project (No. S2013C100537), the College Natural Fund of Jiangsu Province (No. 07kjd210198), the Science and Technology Plan Project of Xuzhou (No. XM13B124); the Plan Project of Xuzhou Institute of Technology (No. xky201013).

\section{REFERENCES}

Baninasab B. 2009. Amelioration of chilling stress by paclobutrazol in watermelon seedlings. Scientia Horticulturae 121: 144-148. DOI: 10.1016/j.scienta.2009.01.028.

Bernacchi C.J., Bagley J.E., Serbin S.P., Ruiz-Vera U.M., Rosenthal D.M., VanLoocke A. 2013. Modelling $\mathrm{C}_{3}$ photosynthesis from the chloroplast to the ecosystem. Plant Cell and Environment 36: 16411657. DOI: 10.1111/pce.12118.

Cai Y.-F., Li S.-F., Li S.-F., Xie W.-J., Song J. 2014. How do leaf anatomies and photosynthesis of three Rhododendron species relate to their natural environments? Botanical Studies 55; 36, 9 p. DOI: 10.1186/1999-3110-55-36.

Conover C.A. 1994. Angel-Wing begonia growth and water requirements affected by Paclobutrazol. Apopka Research Report RH-94-4. University of Florida, Institute of Food and Agricultural Sciences. https://mrec.ifas.ufl.edu/foliage/resrpts/rh_94_4.htm 
Cown D., Marshall H., Silcock P., Meason D. 2013. Sawn timber grade recovery from a planted coast redwood stand growing in New Zealand. New Zealand Journal of Forestry Science 43; 8, 11 p. DOI: 10.1186/1179-5395-43-8.

Davis T.D., Curry E.A., Steffens G.L. 1991. Chemical regulation of vegetative growth. Critical Reviews in Plant Sciences Sci. 10: 151-188. DOI: 10.1080/07352689109382310.

Dwivedi S.K., Arora A., Kumar S. 2017. Paclobutrazolinduced alleviation of water-deficit damage in relation to photosynthetic characteristics and expression of stress markers in contrasting wheat genotypes. Photosynthetica 55: 351-359. DOI: 10.1007/s11099-016-0652-5.

Elanchezhian R., Haris A.A., Kumar S., Singh S.S. 2015. Positive impact of paclobutrazol on gas exchange, chlorophyll fluorescence and yield parameters under submergence stress in rice. Indian Journal of Plant Physiology 20: 111-115. DOI: 10.1007/s40502-015-0144-9.

Fletcher R.A., Gilley A., Sankhla N., Davis T.D. 2000. Triazoles as plant growth regulators and stress protectants. Horticultural Reviews 24: 55-137. DOI: 10.1002/9780470650776.ch3.

Flexas J., Medrano H. 2002. Drought-inhibition of photosynthesis in $\mathrm{C}_{3}$ plants: stomatal and non-stomatal limitations revisited. Annals of Botany 89: 183189. DOI: $10.1093 / \mathrm{aob} / \mathrm{mcf0} 27$.

Genty B., Briantais J.-M., Baker N.R. 1989. The relationship between the quantum yield of photosynthetic electron transport and quenching of chlorophyll fluorescence. Biochimica et Biophysica Acta 990: 8792. DOI: 10.1016/s0304-4165(89)80016-9.

Gilley A., Fletcher R.A. 1997. Relative efficacy of paclobutrazol, propiconazole and tetraconazole as stress protectants in wheat seedlings. Plant Growth Regulation 21: 169-175. DOI: 10.1023/a:1005804717016.

Hu H., Wang L., Li Y., Sun J., Zhou Q., Huang X. 2016a. Insight into mechanism of lanthanum (III) induced damage to plant photosynthesis. Ecotoxicology and Environmental Safety 127: 43-50. DOI: 10.1016/j.ecoenv.2016.01.008.

Hu H., Wang L., Zhou Q., Huang X. 2016b. Combined effects of simulated acid rain and lanthanum chlo- ride on chloroplast structure and functional elements in rice. Environmental Science and Pollution Research 23: 8902-8916. DOI: 10.1007/s11356015-5962-9.

Hunter D.M., Proctor J.T.A. 1994. Paclobutrazol reduces photosynthetic carbon dioxide uptake rate in grapevines. Journal of the American Society for Horticultural Science 119: 486-491. DOI: 10.21273/jashs.119.3.486.

Hu Y., Yu W., Liu T., Shafi M., Song L., Du X. et al. 2017. Effects of paclobutrazol on cultivars of Chinese bayberry (Myrica rubra) under salinity stress. Photosynthetica 55: 443-453. DOI: 10.1007/s11099-016-0658-z.

Januskaitiene I. 2011. Effects of substrate acidity and UV-B radiation on photosynthesis of radishes. Central European Journal of Biology 6: 624-631. DOI: 10.2478/s11535-011-0027-7.

Jones H.G. 1985. Partitioning stomatal and non-stomatal limitations to photosynthesis. Plant, Cell and Environment 8: 95-104. DOI: 10.1111/j.13653040.1985.tb01227.x.

Ju S.M., Gao M.X., Xu D.L. 2007. Research on the cutting for Sequoia sempervirens. Journal of Xuzhou Institute of Technology 22: 40-43. [in Chinese with English abstract]

Ju S.M., Gao M.X., Xu D.L. 2009. Study on the asexual rapid propagation of cold-resistant Sequoia sempervirens. Practical Forestry Technology 1: 23-27. [in Chinese]

Liu C., Xia X., Yin W., Huang L., Zhou J. 2006. Shoot regeneration and somatic embryogenesis from needles of redwood (Sequoia sempervirens (D. Don.) Endl.). Plant Cell Reports 25: 621-628. DOI: 10.1007/s00299-006-0120-y.

Ma Q.-W., Li F.-L., Li C.-S. 2005. The coast redwoods (Sequoia, Taxodiaceae) from the Eocene of Heilongjiang and the Miocene of Yunnan, China. Review of Palaeobotany and Palynology 135: 117129. DOI: 10.1016/j.revpalbo.2005.03.002.

Mataa M., Tominaga S., Kozaki I. 1998. Relative effects of growth retardant (paclobutrazol) and water stress on tree growth and photosynthesis in ponkan (Citrus reticulate Blanco). Journal of the Japanese Society for Horticultural Scienc 67: 28-34. DOI: 10.2503/jjshs.67.28. 
Mohammadi M.H.S., Etemadi N., Arab M.M., Aalifar M., Arab M., Pessarakli M. 2017. Molecular and physiological responses of Iranian Perennial ryegrass as affected by trinexapac ethyl, paclobutrazol and abscisic acid under drought stress. Plant Physiology and Biochemistry 111: 129-143. DOI: 10.1016/j.plaphy.2016.11.014.

Mohammed N.T., Awang Y., Ahmad I., Noori R.S. 2017. Gas exchange, growth and flowering of Lagerstroemia indica treated with different concentration and application techniques of paclobutrazol. Asian Journal of Plant Sciences 16: 37-44. DOI: 10.3923/ajps.2017.37.44.

Moradi S., Baninasab B., Gholami M., Ghobadi C. 2017. Paclobutrazol application enhances antioxidant enzyme activities in pomegranate plants affected by cold stress. Journal of Horticultural Science and Biotechnology 92: 65-71. DOI: 10.1080/14620316.2016.1224605.

Moreira R.A., Fernandes D.R., da Cruz, M.C.M., Lima J.E., de Oliveira A.F. 2016. Water restriction, girdling and paclobutrazol on flowering and production of olive cultivars. Scientia Horticulturae 200: 197-204. DOI: 10.1016/j.scienta.2016.01.014.

Navarro A., Sánchez-Blanco M.J., Bañon S. 2007. Influence of paclobutrazol on water consumption and plant performance of Arbutus unedo seedlings. Scientia Horticulturae 111: 133-139. DOI: 10.1016/j.scienta.2006.10.014.

Olson D.F., Roy D.F., Walters G.A. 1990. Sequoia sempervirens (D. Don) Endl. redwood. In: Burns R.M., Honkala B.H. (Ed.), Silvics of North America; I. Conifers. Agriculture Handbook 654: 541-551.

Pal S., Zhao J., Khan A, Yadav N.S., Batushansky A., Barak S., et al. 2016. Paclobutrazol induces tolerance in tomato to deficit irrigation through diversified effects on plant morphology, physiology and metabolism. Scientific Reports 6: 39321; 13 p. DOI: $10.1038 /$ srep39321.

Polishchuk O.V., Vodka M.V., Belyavskaya N.A., Khomochkin A.P., Zolotareva E.K. 2016. The effect of acid rain on ultrastructure and functional parameters of photosynthetic apparatus in pea leaves. Cell and Tissue Biology 10: 250-257. DOI: 10.1134/s1990519x16030093.
Rademacher W. 1995. Growth retardants: biochemical features and applications in horticulture. Acta Horticulturae 394: 57-73. DOI: 10.17660/actahortic. 1995.394.5.

Schreiber U. 2004. Pulse-Amplitude-Modulation (PAM) fluorometry and saturation pulse method: an overview. In: Papageorgiou Govindjee G.C. (Ed.), Chlorophyll a Fluorescence Advances in Photosynthesis and Respiration 19: 279-319. DOI: 10.1007/978-1-4020-3218-9_11.

Sun J., Hu H., Li Y., Wang L., Zhou Q., Huang X. 2016. Effects and mechanism of acid rain on plant chloroplast ATP synthase. Environmental Science and Pollution Research 23: 18296-18306. DOI: 10.1007/s11356-016-7016-3.

Teto A.A., Laubscher C.P., Ndakidemi P.A., Matimati I. 2016. Paclobutrazol retards vegetative growth in hydroponically-cultured Leonotis leonurus (L.) R.Br. Lamiaceae for a multipurpose flowering potted plant. South African Journal of Botany 106: 6770. DOI: 10.1016/j.sajb.2016.05.012.

Velikova V., Tsonev T., Yordanov I. 1999. Light and $\mathrm{CO}_{2}$ responses of photosynthesis and chlorophyll fluorescence characteristics in bean plants after simulated acid rain. Physiologia Plantarum 107: 77-83. DOI: 10.1034/j.1399-3054.1999.100111.x.

Vu J.C.V., Yelenosky G. 1992. Growth and photosynthesis of sweet orange plants treated with paclobutrazol. Journal of Plant Growth Regulation 11: 85-89. DOI: $10.1007 / \mathrm{bf00198019.}$

Wang Y., Li W., Shi S., Liu L., Xie J., Wei Y. 2012. The chlorophyll fluorescence characteristics change of litchi leaves after sprayed $\mathrm{PP}_{333}$ in winter. Chinese Journal of Tropical Crops 33: 1024-1029. [in Chinese with English abstract]

Yu Y., Zhang L., Wang H., Li C., Niu T., Yan T., Wang C. 2014. Effect ABA and $\mathrm{PP}_{333}$ on the photosynthesis and chlorophyll fluorescence parameters of Cymbidium seedlings which in low temperature stress and its recovery. Journal of Agriculture 4: 30-37. [in Chinese with English abstract]

Zhang J.-W., D'Rozario A., Adams J.M., Li Y., Liang X.-Q., Jacques F.M. et al. 2015. Sequoia maguanensis, a new Miocene relative of the coast redwood, Sequoia sempervirens, from China: Implications for paleogeography and paleoclimate. 
American Journal of Botany 102: 103-118. DOI: 10.3732/ajb.1400347.

Zhao X., Li Y., Zheng M., Bian X., Liu M., Sun Y. et al. 2015. Comparative analysis of growth and photosynthetic characteristics of (Populus simonii $\times$ P. nigra $) \times(P$. nigra $\times$ P. simonii $)$ hybrid clones of different ploidides. PLoS ONE 10; e0119259, 16 p. DOI: 10.1371/journal.pone.0119259.
Zuo X., Qi R., Wang Y., Shao J., Peng M. 2000. Introduction and ecological adaptability of Sequoia sempervirens Endl. in China. Yunnan Forestry Science and Technology 93: 36-40. [in Chinese with English abstract] Zuo X., Bai S., Shao J., Peng M., Qi R., Wang Y. 2003. Growth of Sequoia sempervirens introduced to Yunnan and reforestation prospect. Yunnan Forestry Science and Technology 104: 2-10. [in Chinese with English abstract] 